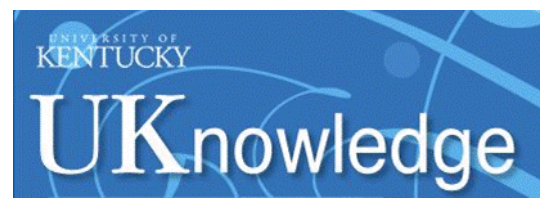

University of Kentucky

UKnowledge

Educational, School, and Counseling

Psychology Faculty Publications

Educational, School, and Counseling

Psychology

9-1981

\title{
The Relationship Between Teacher Attitudes and Student Perceptions of Classroom Climate
}

Jacques S. Benninga

University of Kentucky

Thomas R. Guskey

University of Kentucky, GUSKEY@UKY.EDU

Kathy R. Thornburg

University of Missouri

Follow this and additional works at: https://uknowledge.uky.edu/edp_facpub

Part of the Communication Commons, Educational Assessment, Evaluation, and Research Commons, and the Elementary Education Commons

Right click to open a feedback form in a new tab to let us know how this document benefits you.

\section{Repository Citation}

Benninga, Jacques S.; Guskey, Thomas R.; and Thornburg, Kathy R., "The Relationship Between Teacher Attitudes and Student Perceptions of Classroom Climate" (1981). Educational, School, and Counseling Psychology Faculty Publications. 34.

https://uknowledge.uky.edu/edp_facpub/34

This Article is brought to you for free and open access by the Educational, School, and Counseling Psychology at UKnowledge. It has been accepted for inclusion in Educational, School, and Counseling Psychology Faculty Publications by an authorized administrator of UKnowledge. For more information, please contact UKnowledge@lsv.uky.edu. 


\section{The Relationship Between Teacher Attitudes and Student Perceptions of Classroom Climate}

Digital Object Identifier (DOI)

https://doi.org/10.1086/461242

Notes/Citation Information

Published in The Elementary School Journal, v. 82, no. 1, p. 66-75.

(c) 1981 by The University of Chicago. All rights reserved

The copyright holder has granted the permission for posting the article here.

This article is available at UKnowledge: https://uknowledge.uky.edu/edp_facpub/34 


\section{The Relationship between Teacher Attitudes and Student Perceptions of Classroom Climate}

\author{
Jacques S. Benninga \\ Thomas R. Guskey \\ University of Kentucky
}

Kathy R. Thornburg

University of Missouri, Columbia
The Elementary School Journal

Volume 82, Number 1

(C) 1981 by The University of Chicago. All rights reserved 0013-5984/82/8201-0003\$01.00
Since 1970, when Flanders stressed that "teaching behavior is the most potent, single, controllable factor that can alter learning opportunities in the classroom" (1970, p. 13), an increasing number of educators have come to similar conclusions (Bennett 1976; Gage 1978; Brophy 1979; Good 1979). At the same time, however, many of the studies related to teaching behaviors fail to make clear the distinction between these behaviors and the attitudes and perceptions of teachers. For example, labels associated with certain behavioral characteristics-such as honest, aggressive, authoritarian, destructive, democratic, etc.-are the same labels used to describe attitudes and personality characteristics. According to Hamachek (1978), “. . . people tend to behave in a manner which is consistent with what they believe to be true. In this sense, seeing is not only believing, seeing is behaving" (p. 42). Similar conclusions relating teachers' attitudes and perceptions to their subsequent behavior have been drawn by Good, Biddle, and Brophy (1975) and Clark and Yinger (1979). Thus, if the attitudes and perceptions of teachers affect their behavior and the roles they have defined for themselves (Brophy and Good 1974), it is important to understand these underlying beliefs, particularly since they may have impact on how teachers behave toward pupils (Palardy 1969; Seaver 1973; Pilling and Pringle 1978).

Several studies have explored the relationship between teachers' attitudes and perceptions and their interactions with pupils. Ryans (1964) found that teachers receiving high observer assessments on his 
three major patterns of teacher classroom behavior-warm versus aloof, responsive versus evading, stimulating versus dullcould be clearly distinguished from those teachers receiving low observer assessments. The high group was more favorable in its opinion of students, more likely to employ democratic classroom procedures, and was represented by a mean inventory response suggesting superior emotional adjustment. In a later study focusing on the characteristics of four inner-city schools in which reading achievement was above the national norm, Weber (1971) found that, among other characteristics, teachers in all four schools had "high expectations" for all of their students. Similarly, Rutter et al. (1979) found a positive relationship between pupil achievement and high teacher expectations when they were combined with the use of praise and approval. In a study of elementary schools identified by the Michigan Department of Education as showing either academic improvement or academic failure, Brookover and Lezotte (1979) found that the staffs of the improving schools $(a)$ tended to believe that all of their students could master the basic objectives; $(b)$ held decidedly higher and apparently increasing expectations with regard to the educational accomplishments of their students; $(c)$ were much more likely to assume responsibility for teaching the basic reading and math skills and were much more committed to doing so; and $(d)$ were generally less satisfied than the staffs in the declining schools.

Considering the importance of these attitude differences, a logical question is whether young students can indeed accurately perceive and evaluate these differences in their teachers. Little evidence exists relative to this question. Although a few studies have shown that students in the middle grades and in high school are able to discriminate between their teachers with regard to the quality of teacher-pupil interaction (Amatora 1952; Symonds 1955;
Tuckman and Oliver 1968), younger students appear less able to do so (Pittman 1952; Davis and Slobodian 1967; and Brophy and Good 1974).

Haak, Kleiber, and Peck (1972) reviewed a large body of research related to student evaluations of instruction, and concluded that a case can be argued “. . . at least tentatively (for) the reasonableness of assessing teacher behavior by obtaining young students' perceptions of it. . ." (p. 13). These authors found a "remarkable degree of agreement" in the literature, suggesting that "the warm and friendly teacher who is rated as superior by the students is a mature adult whose focus is outwardly directed toward the children and, furthermore, a person who views the children in a very positive and generous kind of light. The poor teacher appears to be thoroughly ego-centric, concerned with herself, interpreting the students' actions as personally directed toward her own discomfort, and disposed to impugn the motives of others" (p. 29). As a result of their review, Haak et al. felt that sufficient evidence did exist to warrant the development of a group instrument to measure student perceptions of teachers at the lower primary level. If, as has been suggested, teachers' attitudes do affect behavior, and if that behavior has impact on student perceptions about the classroom and resultant student achievement (Page 1958; Staines 1958; Coopersmith and Feldman 1974; Brophy 1979), a study of the interaction of teacher attitudes and student perceptions may have important ramifications for both teachers and teacher educators.

\section{Method}

\section{Subjects}

A total of forty-two classroom units, including all of the first, second, and third grades in a school district contiguous to a large metropolitan area, were selected for the study. Most of the children enrolled in these schools came from middle-class 
homes. Generally, their parents were either employed by one of several colleges or universities in the area or worked at other skilled or professional jobs. The selected first-, second-, and third-grade teachers had a range of classroom experience from 1 to over 30 years, with a mean of 8.3 years. Forty of the teachers were female, and all were Caucasian.

The children included in the study were all those in attendance at the three elementary schools in the district on the testing dates. Included were 378 first graders, 405 second graders, and 364 third graders, for a total of 1,147 primary-level children. There were 606 boys and 541 girls. Testing was completed at the end of October, approximately $2 \frac{1}{2}$ months after the beginning of the school year. It was felt that this 10 -week period was sufficient time for teachers to have made initial determinations as to students' ability levels (i.e., reading group placements, particular behavioral problems, etc.) and to thoroughly familiarize students with classroom procedures. Furthermore, students were well into the second grading period at this time and their daily routine was established.

\section{Design}

This investigation emphasized the relationship between teacher attitudes and students' perceptions of teacher behavior. To assess these relationships, measures of teachers' attitudes and perceptions of their own teaching, and the children's perceptions of their teachers were collected. The measures of teacher attitudes and perceptions of teaching included measures of authoritarianism, control, teaching selfconcept, responsibility for student achievement, and affect toward teaching. Demographic information was also requested of all teachers, including their years of teaching experience, postgraduate education, age, sex, and name. In spite of efforts to reassure the teachers of the anonymity of their responses, a great deal of concern was expressed that the school administration would have access to their responses. Consequently, nineteen of the forty-two teachers did not complete the biographical information as requested. Matched information for teachers and students was thus available for only twenty-three teachers. Relationships among the teacher variables, however, were determined by using the information from all forty-two teachers. In addition, students evaluated their teachers along three dimensions: rapport with students and interactional competence (stimulating interactive style), classroom climate (unreasonable negativity), and fosterage of self-esteem.

\section{Instrumentation}

Teacher variables. All of the teacher variables were measured through the use of self-report questionnaires individually administered to each teacher. Completed questionnaires were collected by the authors several days after dissemination.

The first teacher attitude measure was obtained using the F-Scale, Forms 40 and 45, developed by Adorno et al. (1950). The F-Scale is designed to measure individual prejudices and antidemocratic tendencies. This scale was originally developed in an effort to identify attitudes which would indicate the degree to which a respondent accepted authoritarian beliefs. Scale items indicate the strength of such attitudes as conventionalism, authoritarian submission, superstition, power, destructiveness, and projectivity. A higher score on the F-Scale indicates a greater authoritarian tendency.

The second teacher attitude measure was the Attitude toward the Freedom of Children Scale (Shaw and Wright 1967). This scale contains thirty-three statements concerning children's rights and liberties. Scores on the scale are determined from the median scale values of items with which 
the subject agrees. A higher score on this scale indicates a greater need to control children's behavior, whereas a lower score indicates a more laissez-faire, childcentered attitude in dealing with children.

The final three questionnaires were randomly arranged in a booklet together with instructions. One of the questionnaires was the Responsibility for Student Achievement Questionnaire (RSA) developed by Guskey (1980). This scale contains thirty alternative weighting items which assess teachers' beliefs in their own control of factors influencing the academic successes and failures of their students. Two subscale scores are obtained from the RSA, one assessing self-responsibility for positive events in the classroom $(\mathrm{R}+)$ and the other measuring self-responsibility for negative classroom events $(\mathbf{R}-)$. The $\mathbf{R}+$ subscale is reported to have an internal reliability of .79 , while that of the $R$ - subscale is .88 .

A second questionnaire was designed to assess affect toward teaching; that is, how much teachers like teaching and how positively or negatively they feel about various aspects of teaching. This measure consists of thirty Likert-type rating scale items, most of which were adopted from items contained in the Self-Observational Scales (SOS) for students (Katzenmeyer and Stenner 1974). Each of the items in this questionnaire asked teachers to indicate their feelings in regard to a particular statement. Five options were available for the rating, ranging from strongly agree to strongly disagree. The statements were both positive and negative. For example, a positive item would be, "I enjoy learning about new classroom techniques"; while a negative item would be, "I often get bored in discussions about education." The weights assigned to response options were reversed for negative items. Pilot testing of this scale showed it to be fairly reliable, with a Cronbach alpha coefficient of $\mathbf{8 5}$.

The third questionnaire contained in the booklet assessed teaching self-concept. This scale also consists of thirty Likert-type rating scale items adopted from similar behaviorally based self-concept items developed in the research of Brookover (1973). For each item teachers indicated their feelings in relation to particular behaviors or characteristics relevant to teaching. Items were both positive and negative and were also rated on a fivepoint scale from strongly agree to strongly disagree. Again, response weights were reversed for negative items. An example of a positive item would be, "Most of my students consider my class worthwhile"; while a negative item would be, "I often have doubts about my teaching effectiveness." Pilot testing of this scale also showed it to be quite reliable, with a Cronbach alpha coefficient of .84 .

Student variables. Children's perceptions of their teachers were measured by using the Student Evaluation of Teaching II (SET II), a group measure developed by Haak et al. (1972). This instrument contained twenty-three statements, on cards, individually packaged for each child. After identifying a card, its statement was read aloud to the group (e.g., "The next card has a picture of a flower on it. The card says 'She is nice when we make mistakes.' If Ms. Jones is nice when you make mistakes, put the flower card in the mailbox folder. If Ms. Jones is not nice when you make mistakes, put the flower card in the trashcan folder"). In scoring this instrument, statements were divided into three major categories: stimulating interactive style, classroom climate (unreasonable negativity), and fosterage of self-esteem.

\section{Results}

Our first step in analyzing the data was to calculate the scale score means and standard deviations for each of the teacher and student variables. Comparisons between measures obtained from teachers who participated fully $(N=23)$ and those 
teachers whose data could not be matched with student data $(N=19)$ are illustrated in table 1. Scores on the three student measures represent average teacher ratings by students on these variables.

Table 2 shows the intercorrelations between teacher and student variables. Again, relationships involving student variables were computed using only those teachers with matched student data. Several of these correlations were statistically significant and the direction of the interrelationships between several other variables indicates a number of interesting tendencies.

Teachers' affect toward teaching scores

TABLE 1. Means and Standard Deviations of Teacher and Student Variables

\begin{tabular}{|c|c|c|c|c|}
\hline \multirow[b]{3}{*}{ Variables } & \multicolumn{4}{|c|}{ Group } \\
\hline & \multicolumn{2}{|c|}{ Fully Participating $(N=23)$} & \multicolumn{2}{|c|}{ Nonmatched $(N=19)$} \\
\hline & $\bar{X}$ & SD & $\bar{X}$ & SD \\
\hline \multicolumn{5}{|l|}{ Teacher variables: } \\
\hline F-Scale & 109.19 & $(22.30)$ & 107.68 & (17.03) \\
\hline Freedom of children & 6.13 & $(.62)$ & 5.92 & $(.78)$ \\
\hline $\mathrm{R}+$ scale & 53.08 & $(4.25)$ & 52.42 & $(4.78)$ \\
\hline $\mathrm{R}$ - scale & 47.23 & $(3.48)$ & 43.64 & $(7.92)$ \\
\hline Affect toward teaching & 103.61 & (9.92) & 105.05 & $(10.75)$ \\
\hline Teaching self-concept & 96.04 & $(4.99)$ & 95.89 & $(4.69)$ \\
\hline \multicolumn{5}{|l|}{ Student variables: } \\
\hline Interactive style & 10.21 & $(.54)$ & 10.02 & $(.60)$ \\
\hline Negativity & 8.73 & $(.50)$ & 8.78 & $(.59)$ \\
\hline Fostering self-esteem & 7.09 & $(.37)$ & 6.93 & $(.58)$ \\
\hline
\end{tabular}

NotE.-Scores on the three student variables represent average teacher ratings by students on these variables.

TABLE 2. Intercorrelations among Teacher and Student Variables Corrected for Attenuation $(N=42)$

\begin{tabular}{|c|c|c|c|c|c|c|c|c|c|}
\hline \multirow[b]{2}{*}{ Variables } & \multicolumn{6}{|c|}{ Teacher Variables } & \multicolumn{3}{|c|}{ Student Variables } \\
\hline & F-Scale & $\begin{array}{l}\text { Freedom } \\
\text { of } \\
\text { Children }\end{array}$ & $\begin{array}{l}\mathrm{R}+ \\
\text { Scale }\end{array}$ & $\begin{array}{l}\mathrm{R}- \\
\text { Scale }\end{array}$ & $\begin{array}{c}\text { Affect } \\
\text { toward } \\
\text { Teaching }\end{array}$ & $\begin{array}{l}\text { Teaching } \\
\text { Self- } \\
\text { Concept }\end{array}$ & $\begin{array}{l}\text { Inter- } \\
\text { active } \\
\text { Style }\end{array}$ & $\begin{array}{c}\text { Negativ- } \\
\text { ity }\end{array}$ & $\begin{array}{c}\text { Fostering } \\
\text { Self- } \\
\text { Esteem }\end{array}$ \\
\hline \multicolumn{10}{|l|}{$\begin{array}{l}\text { Teacher vari- } \\
\text { ables: }\end{array}$} \\
\hline F-Scale & 1.00 & .188 & -.198 & .184 & -.278 & .218 & -.099 & -.188 & .107 \\
\hline children & & 1.00 & .166 & -.202 & -.186 & $.303^{*}$ & $-.319 *$ & .022 & -.098 \\
\hline $\mathrm{R}+$ scale & & & 1.00 & .228 & $.401 *$ & $-.332 *$ & .293 & -.105 & -.046 \\
\hline $\mathrm{R}$ - scale & & & & 1.00 & -.208 & .088 & -.097 & -.117 & -.067 \\
\hline $\begin{array}{l}\text { Affect toward } \\
\text { teaching } \\
\text { Teaching }\end{array}$ & & & & & 1.00 & -.130 & -.100 & -.138 & .232 \\
\hline $\begin{array}{l}\text { self-concept } \\
\text { Student vari- } \\
\text { ables: }\end{array}$ & & & & & & 1.00 & -.083 & -.030 & -.222 \\
\hline Interactive style & & & & & & & 1.00 & $-.341 *$ & $.627 *$ \\
\hline Negativity & & & & & & & & 1.00 & $-.506^{*}$ \\
\hline $\begin{array}{l}\text { Fostering } \\
\text { self-esteem }\end{array}$ & & & & & & & & & 1.00 \\
\hline
\end{tabular}

Note.--Intercorrelations with student variables were computed using only the twenty-three teachers for whom matched data were available.

$* p<.05$. 
were all in a direction consistent with expected trends. That is, teachers who liked teaching more tended to be less authoritarian, felt less need to control their students, and felt greater responsibility for positive student learning outcomes. Teachers who reported higher teaching self-concepts, on the other hand, tended to be more authoritarian, were more restrictive in regard to children's freedom, and felt less responsibility for positive student learning outcomes.

Thus two typologies seemed to emerge. One type of teacher appeared to like teaching, felt responsible for positive classroom events, and was more open and democratic. The other type seemed to have a higher self-regard but a more controlling, authoritarian perspective on children.

The students of these teachers, however, did not seem to identify these teacher differences. Only one correlation between teacher and student variables proved to be significant. As teachers felt a greater need to control children (Attitude toward the Freedom of Children Scale), they were seen by their students as having less rapport (interactive style). In other words, the more controlling teachers were seen by their students as not making school fun, not listening to what they wanted, not liking to teach, and not helping them. A positive correlation which approached significance was found between teachers' responsibility for positive classroom events $(\mathrm{R}+$ scale $)$ and the students' perception of teachers' interactive style.

Our data did show that the students were very consistent in their perceptions of the teachers. Those teachers who were rated by their students as highly interactive were also rated as not negative (e.g., students rated them low on such items as "She gets mad a lot," "She thinks I act ugly") and as fostering self-esteem (e.g., "She likes me," "She thinks I can do a lot on my own").

To further investigate relationships among these variables, the sample of twenty-three teachers for whom student data could be matched was subdivided according to grade level taught and number of years of teaching experience. As can be seen in table 3 , the grade level at which a teacher taught (within this narrow range) had little effect upon students' ratings of the teacher. Grade 1 teachers did tend to receive consistently more positive ratings than Grade 3 teachers; however, these differences were not statistically significant.

In regard to years of teaching experience, the data in table 4 show, little difference between the groups. There was a tendency for less experienced teachers to receive more positive ratings from their students than did teachers with many years of experience, but again this difference

TABLE 3. Means and Standard Deviations of Student Ratings of Teachers at Different Grade Levels

\begin{tabular}{lccc}
\hline & \multicolumn{3}{c}{ Teaching Level } \\
\cline { 2 - 4 } & & & \\
\multirow{2}{*}{ Student Rating } & $\begin{array}{c}\text { Grade 1 } \\
(N=8)\end{array}$ & $\begin{array}{c}\text { Grade 2 } \\
(N=8)\end{array}$ & $\begin{array}{c}\text { Grade 3 } \\
(N=7)\end{array}$ \\
\hline Interactive style & 10.24 & 10.43 & 10.07 \\
& $(.44)$ & $(.56)$ & $(.63)$ \\
Negativity & 8.53 & 8.80 & 8.90 \\
Fostering self-esteem & $(.48)$ & $(.51)$ & $(.52)$ \\
& 7.19 & 7.04 & 6.90 \\
& $(.32)$ & $(.40)$ & $(.38)$ \\
\hline
\end{tabular}

TABLE 4. Means and Standard Deviations of Student Ratings of Teachers with Different Levels of Experience

\begin{tabular}{lccc}
\hline & Number of Years Teaching \\
& \multicolumn{3}{c}{ Experience } \\
\cline { 2 - 4 } \multicolumn{1}{c}{ Student Rating } & $1-3$ & $4-12$ & $12+$ \\
& $(N=5)$ & $(N=13)$ & $(N=5)$ \\
\hline Average years & 1.80 & 7.38 & 26.40 \\
experience & $(.84)$ & $(2.84)$ & $(4.04)$ \\
Interactive style & 10.23 & 10.34 & 9.87 \\
& $(.67)$ & $(.49)$ & $(.51)$ \\
Negativity & 8.42 & 8.72 & 9.10 \\
& $(.50)$ & $(.47)$ & $(.41)$ \\
Fostering self-esteem & 7.17 & 7.11 & 6.90 \\
& $(.60)$ & $(.32)$ & $(.23)$ \\
\hline
\end{tabular}


TABLE 5. Means and Standard Deviations of Student Ratings of Teachers by Student Gender

\begin{tabular}{lcc}
\hline \multicolumn{1}{c}{ Student Rating } & $\begin{array}{c}\text { Male } \\
\text { Students } \\
(N=606)\end{array}$ & $\begin{array}{c}\text { Female } \\
\text { Students } \\
(N=541)\end{array}$ \\
\hline Interactive style & 10.40 & 10.09 \\
& $(1.32)$ & $(1.21)$ \\
Negativity & 8.69 & 8.80 \\
& $(1.26)$ & $(1.19)$ \\
Fostering self-esteem & 7.18 & 6.95 \\
& $(1.26)$ & $(1.13)$ \\
\hline
\end{tabular}

failed to meet the criteria of statistical significance.

Differences among the mean scores given teachers by students (matched and unmatched samples combined) of different sexes were next explored. Male students consistently rated their female teachers more positively than did female students, although this difference was not statistically significant.

\section{Discussion}

Our major hypothesis relating to young children's ability to accurately perceive attitudinal differences in their teachers was partially supported. Our data show that teachers who felt a greater need to exercise control over their students and felt less responsible for the positive learning outcomes of their students were perceived by their students more negatively than those teachers who felt less need to control and who felt more personal responsibility.

Our data also suggest that teachers who report higher teaching self-concepts tend to feel less responsibility for positive classroom events, and their students appear to be sensitive to this lack of involvement. Teachers who report lower teaching selfconcepts, on the other hand, appear to accept greater responsibility for positive student outcomes. Since these data are correlational, and thus imply no cause-andeffect relationship, the reasons for these relationships cannot be determined from the present study. However, the explana- tion of such patterns would be an important question for future research.

Research on parenting styles may be seen as having parallel implications. Baldwin (1948), for example, found that highly democratic parents had children who were bossy, physically vigorous and active, and highly socially involved, while highly controlling parents had children who were obedient, suggestible, fearful, and lacking in tenacity. Similarly, the students of highly democratic teachers might be expected to be more independent and boisterous, while those students of more controlling teachers might be expected to be quieter and more obedient. Having greater control over students may be reassuring to many teachers, and hence they may feel better about themselves as teachers in settings where effective teaching is equated with maintaining control.

Highly controlling parents who are greatly concerned with maintaining authority and who value obedience for its own sake also have been found to have children who are lacking in empathy (Feshbach 1974), are low in self-esteem (Coopersmith 1967), are poor in the internalization of moral standards (Hoffman and Saltzstein 1967), are frequently sad and withdrawn, and who lack a sense of independence (Baumrind 1971, 1973). However, Baumrind found that when parents imposed fairly high demands on their children, while at the same time encouraging verbal give and take in their explanations of, and rationales for, desired behavior, their children were more independent and socially responsible.

Extending these findings to the classroom setting, teachers who feel a greater sense of responsibility for positive learning outcomes may foster in their students a desire to perform at higher levels (Weber 1971; Brookover and Lezotte 1979; and Rutter et al. 1979), with more positive classroom interactions (interactive style) resulting as a by-product of these attitudes. Undoubtedly, the influence of parents is 
much greater than the influence of a single teacher. However, the implications of these parenting studies do seem noteworthy, particularly in regard to primary-level children.

Our analysis of grade level differences among students in their ratings of teacher attitudes revealed that first-, second-, and third-grade students all rated their teachers quite positively in comparison with established norms. First graders tended to rate their teachers more highly than did third graders. These results may be interpreted from a developmental perspective. Young children, because of their egocentricity, tend to have unilateral respect for authority figures (Piaget 1965). The youngest children would thus interpret almost any action of the authority as the correct action, and therefore teacher ratings would be positive. As children develop, this social orientation changes from one of unilateral respect to one of cooperation, implying the gratification of needs on both sides. Thus, as children mature one might expect them to become more discriminating in the evaluation of their teachers. Given the variation in personality dimensions found in this study and the uniformity of student evaluations, the foregoing explanation seems justifiable, especially in light of recent studies which indicate that teachers tend to be more disapproving of male students (Lee and Wolinsky 1973; Brophy and Good 1974; Etaugh and Harlow 1975). Despite such differential teacher behavior, our young male subjects continued to rate their teachers highly.

This study was somewhat limited by the fact that the responses of nineteen teachers could not be matched with the responses of their students because they chose not to complete the biographical information called for on the questionnaires. The teachers surveyed were interested in our research and were willing to cooperate; however, despite our efforts to convince them otherwise, they remained concerned about the anonymity of their responses. This is not an uncommon problem in educational research, and care should be taken to secure a large enough sample in studies of this type to ensure the usability of the results. While comparisons did show that the unidentified teachers in our sample rated themselves quite similarly to the experimental teachers, the size of our original sample was greatly reduced.

The results of the study do suggest that certain teacher attitudes are related to student perceptions of teachers. If teaching behaviors are influenced by teacher attitudes, changes in teacher behavior may also change attitudes. If teachers had available to them more effective interactive techniques to use in the classroom (e.g., Brophy 1979), it seems likely that they might assume more responsibility for student outcomes and might, in the process, change their attitudes toward students. Research on changing student outcomes through alterations in teacher behavior may have only short-term effects if the changes in teacher behavior are not linked to a concurrent change in teacher attitudes. This area should not be overlooked by educational researchers.

Note

An earlier version of this paper was presented to the International Congress on Early Childhood Education, Tel Aviv, Israel, January 1980 .

\section{References}

Adorno, T.; Frenkel-Brunswik, W.; Levinson, D.; and Sanford, R. The Authoritarian Personality. New York: W. W. Norton \& Co., 1950.

Amatora, Sister M. "Can Elementary School Children Discriminate Certain Traits in Their Teachers?" Child Development 23 (1952): 75-80. 
Baldwin, A. L. "Socialization and the ParentChild Relationship." Child Development 19 (1948): 127-36.

Baumrind, D. "Current Patterns of Parental Authority." Developmental Psychology Monograph 4 (1971): 1, part 2.

Baumrind, D. "The Development of Instrumental Competence through Socialization." In Minnesota Symposium on Child Psychology, edited by A. D. Pick. Vol. 7. Minneapolis: University of Minnesota Press, 1973.

Bennett, S. N. Teaching Styles and Pupil Progress. London: Open Books, 1976.

Brookover, W. B. Identification and Analysis of Elementary School Social Environment Characteristics Associated with Differential School Performance, Socio-Economic Status and Racial Composition of the Schools Controlled. U.S. Office of Education Cooperative Research Project. East Lansing: Michigan State University Press, 1973.

Brookover, W. B., and Lezotte, L. W. Changes in School Characteristics Coincident with Changes in Student Achievement. East Lansing: Michigan State University, Institute for Research on Teaching, 1979.

Brophy, J. E. "Teacher Behavior and Its Effects." Journal of Educational Psychology 71 (1979): 733-50.

Brophy, J. E., and Good, T. W. Teacher-Student Relationships: Causes and Consequences. New York: Holt, Rinehart \& Winston, 1974.

Clark, C. M., and Yinger, R. J. “Teachers' Thinking." In Research on Teaching: Concepts, Findings and Implications, edited by P. L. Peterson and H. J. Walberg. Berkeley: McCutchan Publishing Corp., 1979.

Coopersmith, S. The Antecedents of Self-Esteem. San Francisco: W. H. Freeman \& Co., 1967.

Coopersmith, S., and Feldman, R. "Fostering a Positive Self-Concept and High Self-Esteem in the Classroom." In Psychological Concepts in the Classroom, edited by R. H. Coop and K. White. New York: Harper \& Row, 1974.

Davis, O. L., and Slobodian, J. J. "Teacher Behavior toward Boys and Girls during First Grade Reading Instruction." American Education Research Journal 4 (1967): 261-70.

Etaugh, C., and Harlow, H. "Behaviors of Male and Female Teachers as Related to Behaviors and Attitudes of Elementary School Children."Journal of Genetic Psychology 127 (1975): 163-70.

Feshbach, S. "The Development and Regulation of Aggression: Some Research Gaps and a Proposed Cognitive Approach." In Determinants and Origins of Aggressive Behavior, edited by J. DeWit and W. W. Hartup.
The Hague: Mouton Press, 1974.

Flanders, N. Analyzing Teacher Behavior. Reading, Mass.: Addison-Wesley Publishing Co., 1970.

Gage, N. The Scientific Basis of the Art of Teaching. New York: Teachers College Press, 1978.

Good, T. "Teacher Effectiveness in the Elementary School: What We Know about It Now." Journal of Teacher Education 30 (1979): 52-64.

Good, T. L.; Biddle, B. J.; and Brophy, J. E. Teachers Make a Difference. New York: Holt, Rinehart \& Winston, 1975.

Guskey, T. R. "Teachers' Beliefs in Their Own Control of Factors Influencing the Academic Achievement of Students." Paper presented at the annual meeting of the American Educational Research Association, Boston, 1980.

Haak, R. A.; Kleiber, D. A.; and Peck, R. Student Evaluation of Teacher Instrument II. Austin: University of Texas, Research and Development Center for Teacher Education, 1972.

Hamachek, D. E. Encounters with the Self. New York: Holt, Rinehart \& Winston, 1978.

Hoffman, M. L., and Saltzstein, H. D. "Parent Discipline and the Child's Moral Development." Journal of Personality and Social Psychology 5 (1967): 45-47.

Katzenmeyer, W. G., and Stenner, A. J. Self Observational Scales (SOS). Durham, N.C.: National Testing Service, 1974.

Lee, P., and Wolinsky, A. "Male Teachers of Young Children: A Preliminary Empirical Study." Young Children 27 (1973): 342-52.

Page, E. E. "Teacher Comments and Student Performance." Journal of Educational Psychology 46 (1958): 173-81.

Palardy, M. J. "What Teachers Believe, What Children Achieve." Elementary School Joumal 69 (1969): 370-74.

Piaget, J. The Moral Judgment of the Child. Translated by Marjorie Gabain. New York: Free Press, 1965.

Pilling, D., and Pringle, M. K. Controversial Issues in Child Development. London: Elek Books, 1978.

Pittman, J. A. "A Study of the Suitability of an Attitude-gauging Instrument for Assaying the Attitude-toward-Schooling of a Group of Sixth Grade Negro Pupils." Journal of Negro Education 2 (1952): 136-47.

Rutter, M.; Maughan, B.; Mortimore, P.; Ouston, J.; and Smith, A. Fifteen Thousand Hours: Secondary Schools and Their Effects on Children. Cambridge, Mass.: Harvard University Press, 1979.

Ryans, D. C. "Research on Teacher Behavior in the Context of the Teacher Characteristics 
Study." In Contemporary Research on Teacher Effectiveness, edited by B. J. Biddle and W. Ellena. New York: Holt, Rinehart \& Winston, 1964.

Seaver, W. B. "Effects of Naturally Induced Teacher Expectancies." Journal of Personality and Social Psychology 28 (1973): 333-42.

Shaw, M., and Wright, J. Scales for the Measurement of Attitudes. New York: McGraw-Hill Book Co., 1967.

Staines, J. W. "The Self-Picture as a Factor in the Classroom." British Journal of Educational
Psychology 28 (1958): 97-111.

Symonds, P. M. "Characteristics of the Effective Teacher Based on Pupil Evaluations." Journal of Experimental Education 23 (1955): 289-310.

Tuckman, B. W., and Oliver, W. F. "Effectiveness of Feedback to Teachers as a Function of Source." Journal of Educational Psychology 59 (1968): 297-301.

Weber, G. Inner-City Children Can Be Taught to Read: Four Successful Schools. Washington, D.C.: Council for Basic Education, 1971. 